岩石鉱物鉱床学会誌

65 券 6 号, 1971 年

\title{
STRATIGRAPHY AND PETROLOGY OF THE LOW-GRADE REGIONALLY METAMORPHOSED ROCKS OF THE EOCENE FORMATION IN THE ALBORZ RANGE, NORTH OF TEHRAN, IRAN
}

\author{
Shuichi Iwao* and A. Hushmand-ZadeH** \\ * United Nations, Geological Survey Institute of Iran \\ Present address: Geological Institute, Faculty of Science, University \\ of Tokyo \\ ** Geological Survey Institute of Iran
}

\begin{abstract}
Field investigation in 1965 and subsequent petrographic observations established the following stratigraphic division, in ascending order, of the Eocene submarine volcanic and pyroclastic complex called "Karaj Formation" (formerly "Green Series"): 1, Sarband Basic Volcanic Member; 2, Lower Tuff Member; 3, Middle Tuff Member; 4, Astara Shale Member; 5, Upper Tuff Member.

These units form a thick pile of continuous accumulation, without stratigraphic breaks, of volcanic, muddy, and marly sediments, in which dacitic pyroclastic rocks are the major constituents of the upper and middle horizons and basic volcanics predominate in lower the horizons.

In spite of the great total thickness of the Karaj Formation (more than $10,000 \mathrm{~m}$ ), there is no distinct evidence of bathyal sedimentation and extrusion. Convolution and double-graded bedding of the acid pyroclastics are common.

The volcanic rocks and pyroclastics have undergone low-grade regional metamorphism deriving from deep burial. The metamorphic rocks of the upper stratigraphic horizons correspond to a zeolitic facies. With transition of metamorphic features, they are underlain by rocks in which epidote and or prehnite are characteristic and pumpellyite is absent; petrographic features differ from those of greenschist facies. They can be regarded as a subfacies in the prehnite-pumpellyite-metagreywacke facies group. Laumontite predominates in pyroclastics only in the metamorphic halo coating the monzonite sills near Karaj dam.

The Karj Formation is rather similar in major metamorphic features to the largest part of the "Green Tuff" Formation of Miocene age in Japan, but seems to have been metamorphosed under a lower geothermal gradient.
\end{abstract}

\section{INTRODUCTION}

The area described in this paper is situated to the north of Tehran and

(Manuscript received April 19, 1971) 
occupies the southern margin of the central part of the Alborz Mountains. The area is about $45 \mathrm{~km}$ by $20 \mathrm{~km}$ in east-west and north-south directions, respectively. The field work was carried out during the August and the first week of September, 1965, as part of the mapping programme for the Tehran Quadrangle map $(1: 250,000$, unpublished), which covers the adjacent areas studied by other geologists.

As very little petrographic work had been done in this and adjacent areas, the authors studied in detail the lithologic and petrologic characteristics of the volcanic and pyroclastic rocks, particularly with respect to their metamorphism.

The field investigation revealed that all of the volcanic and pyroclastic rocks exposed in the area belong to the Eocene Karaj Formation (formerly "Green Series") and that they can be subdvided into four major stratigraphic units which continue into surrounding areas. The geologic structure is rather simple and extends westward with little change in general lithofacies

A discovery of petrographic interest was the identification, in the volcanic and pyroclastic rocks, of primary mineral associations very similar to those in the submarine volcanic clan in the Miocene basins in Japan. Another result was the finding of a characteristic low-grade regional metamorphism comprising a zeolitic facies and a subfacies of the prehnite-pumpellyite metagraywacke facies, relating to depth of burial of the Eocene strata. Brief petrographic notes are given in later paragraphs.

In the northern part of the area, the Karaj Formation is separated from older formations by a thrust fault. The southern extension of the Karaj Formation is cut by a fault against the Quaternary conglomerate formations around Tehran. Two gentle synclinal basins are separated by sharp anticlines. The total amount of elevation attained in this area amounts to at least 10,000 meters, and possibly around 15,000 meters.

\section{AGKNOWLEDGEMENTS}

The writers express their thanks to the United Nations and the Geological Survey of Iran for permission to publish this paper; their special thanks go to Mr. N. Khadem, Director, and to Dr. G.J. Williams, U.N. Project Manager. Dr. J. Stöcklin, Chief Geologist, who encouraged the work by critical discussions. Miss. Jean Luke has kindly edited the text. Grateful acknowledgement is expressed to Prof. N. Katayama of the University of Tokyo for X-ray studies of zeolites from the Middle Tuff Member. Our hearty thanks are also due to Miss. T. Konno who helped us for preparing the figures.

\section{STRATIGRAPHY AND LITHOLOGY}

1. General Remarks: The whole sequence of Eocene strata, the Karaj 


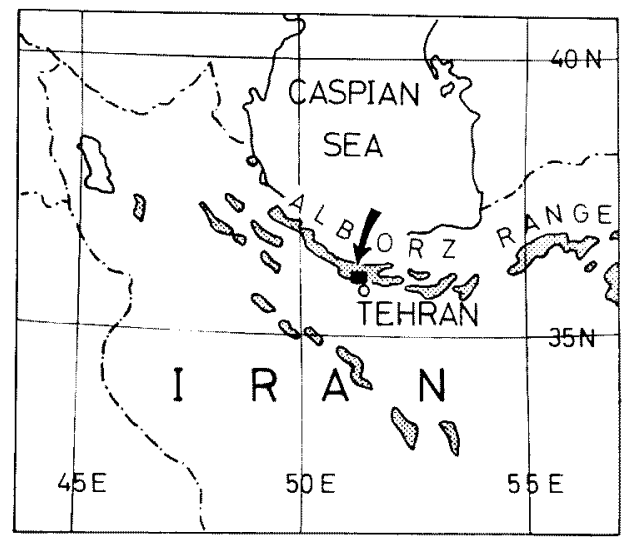

Fig. 1. Locality map of the investigated area, showing the distribution of Eocene volcanoes and volcanosediments. (cited from Geological Map of Iran, 1: 2500,000 compiled by the Geological Stuff of the Iran Oil Company, 1959)

Formation, which is characterized by submarine volcanic material of dacitic, andesitic, and, to a smaller extent, rhyolitic composition, continues from the Touchal Mountain Area to the north-west, where it was investigated by Dedual (1967) and Lorenz (1964). These authors introduced the subdivisions and names, Lower Tuff Member, Middle Tuff Member, Astara Shales, Upper Tuff Member, and Kandevan Shales in ascending sequence. No important structural or stratigraphic differences exist between the northwestern area (Karaj Valley) and the Touchal Mountain Area.

The basic volcanic rocks forming the lowest horizons in the southwestern part of the Touchal Mountain Area, for which the present writers propose the stratigraphic name "Sarband Basic Volcanic Member", are very thick. The stratigraphic position of the volcanic strata at the southwestern foot of the mountain is questionable. Around Kondor village are thick intercalations of andesitic pyroclastics, lavas, and well-stratified, black, silty mudstone which the authors name the "Kondor Volcanic Submember". The conglomerate formations developed at the southern foot of the mountain, which have an entirely different structural pattern, seem to comprise Quaternary and later alluvial deposits.

2. Sarband Basic Volcanic Member: The entire sequence of strata in this member is exposed along the road from Tajrish to Ab-Shar. The member is composed of a thick alternation of lava flows, flow breccias, agglomerates, coarse tuff-breccias, and tuffs, of andesitic composition. 
Occasionally, in the lower and upper horizons, the strata are intercalated with thin beds of black shale and mudstone. The andesite lavas comprise hornblende-augite andesite and augite andesite. They are dark-green owing to chloritization and do not have any particular internal structure or joint systems; they are partly transitional to flow breccias. Each lava flow is less than $50 \mathrm{~m}$ thick.

The hornblende-augite andesite which occurs typically as lava flows just north of Shemiran is porphyritic, with phenocrysts of calcic plagioclase laths, monoclinic pyroxene, and a glassy substance. Besides chlorite and secondary albitic plagioclase, secondary minerals such as titanite, prehnite, epidote, and quartz are common. They are penetrated by veinlets of epidote.

The augite andesite occurs typically as compact lava flows just on the top of the intercalated black shale, north of Shemiran. It is holocrystalline and subophitic, with conspicuously zoned calcic plagioclase. Chlorite, sericite, titanite, epidote, albite, and calcite are the secondary products, the last three forming veinlets.

In the eastern part, to the north of Manzarieh and east of Ab-Shar, the agglomerates attain a thickness of more than $500 \mathrm{~m}$. The maximum diameter of the bombs of the agglomerates is about $25 \mathrm{~cm}$. They are mostly porphyritic andesite and partly of amygdaloidal augite andesite. They suffered albitization, epidotization, and chloritization. Epidote-calcite and albite aggregates occur as pools and veinlets. Cavity-filling quartz, chlorite, and epidote are common in the amygdalodcal andesite.

The mudstones and shales are well stratified, often thinly laminated and intercalated with dacitic light-grey fine tuff.

The lower limit of the Basic Volcanic Member is not known in this area, but the total exposed thickness of this member is about $2,000 \mathrm{~m}$.

3. Lower Tuff Member: The strata of the Lower Tuff Member overlie the Sarband Basic Volcanic Member conformably. Their maximum thickness is about $1,500 \mathrm{~m}$ on the southern slope of Mt. Touchal. The lower part is very rich in dacitic pyroclastics and lava flows, the middle part is dominated by black shales, and the upper part is characterized by basic lavas and intrusive sills.

The dacitic lava flows are well exposed in the valley of Darrekeh. They are generally massive without flow bands, are porphyritic or aphanitic, and show light grey or light pinkish-grey colours on the outcrops. In some parts, however, they assume the structure of flow-breccias. The maximum total thickness of the lava flows is about $700 \mathrm{~m}$.

The dacite lavas exposed near Ab-Shar comprise biotite dacite and porphyritic dacite. The biotite dacite lava is fluidal in texture and has a few phenocrysts of plagioclase and biotite. 


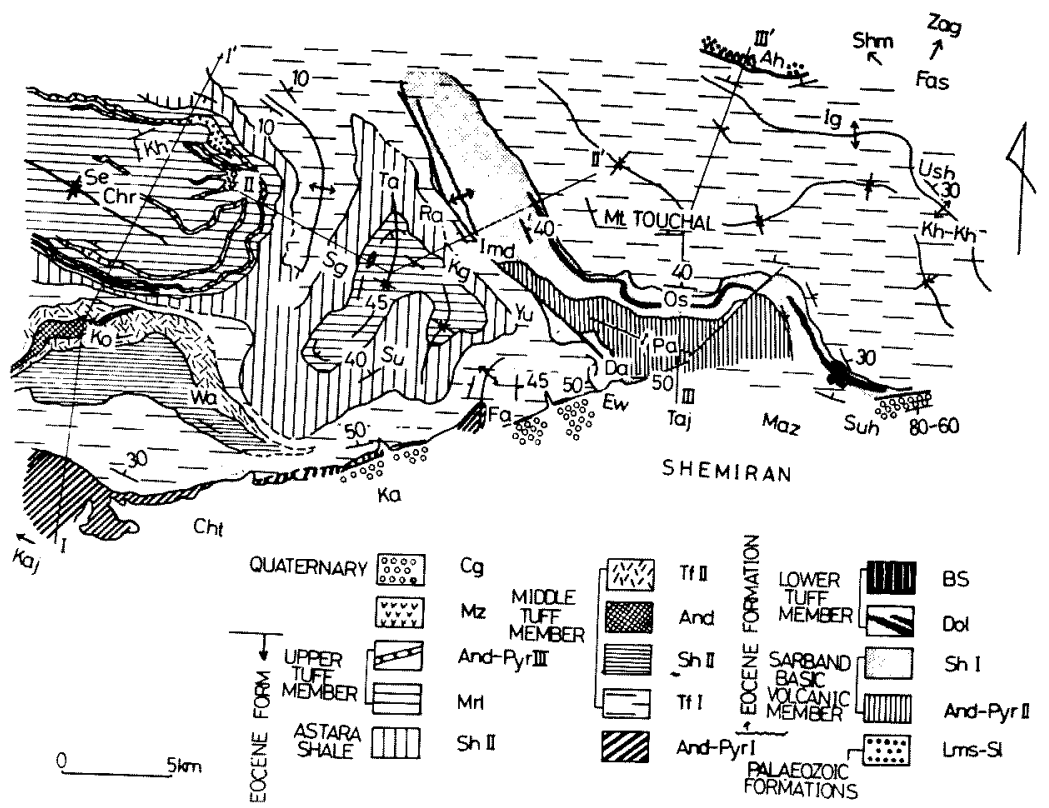

Fig. 2. Geological Map of the area around Mt. Touchal, Alborz Range, north of Tehran. (S. Iwao and A. Hushmand-Zadeh, 1965)

$\mathrm{Cg}$ : Quaternary conglomerate $\mathrm{Mz}$ : Intrusive sills of monzonite porphyry And-Pyr III : Andesite lavas of Upper Tuff Member Mri : Dacitic pryoclastic sediments with intercalation of marly shale Sh II : Black shale of Astara Shale Member Tf II : Kondor volcanic rocks and volcanosediments mostly of andesite clan. And: Andesite lavas of Kondor Volcanic Submember Sh III : Mudstone and shale of Kondor Mudstone Submember Tf I : Dacite (light dacite) pyroclastics with minor association of lava flows And-Pyr I : Andesite lava flows; stratigraphic horizon unknown Bs : Basaltic lava Dol : Dolerite intrusive sills Sh I : Black shale of Lower Tuff Member And Pyr II : Andesite lava and pyroclastic sediments Lms-Sl : Alternation of limestone and slate Ah: Ahar Cht : Chitgar Da: Darrakeh Fa :

Farahzad

Kaj : Karaj

Osun-Abshar

Tajrish

Yunjehzar
Imd : Imamzadehdavoud

$$
\text { Kh : Khur }
$$

$\mathrm{Ra}$ : Randan

Ush : Ushan
Ko : Kondor

Suh : Suhanak

Wa : Wardi
$\mathrm{Ka}$ : Kand

Os :

Taj :

$\mathrm{Y}_{\mathrm{u}}$ :

To the south of Ab-Shar, well stratified, dacite coarse tuff-breccia accompanied by lava flows predominates. In places the lava flows have 

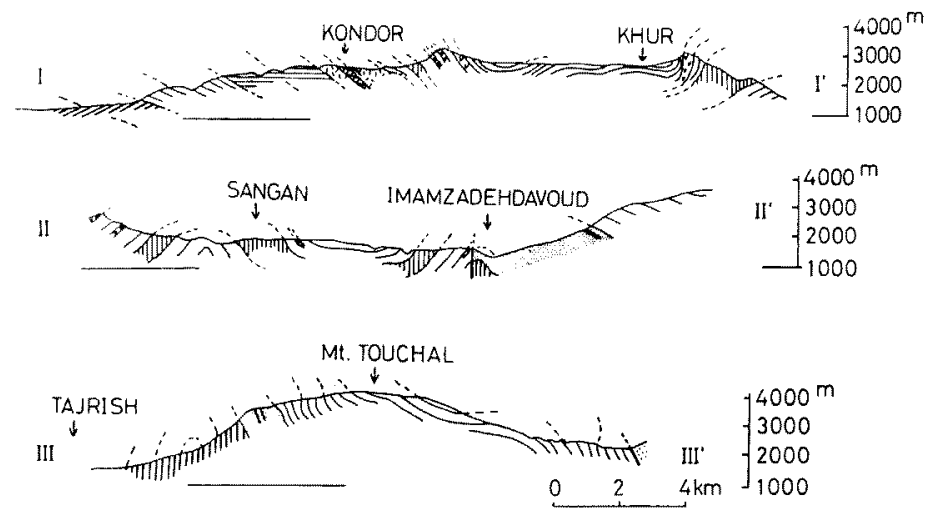

Fig. 3. Geologic profiles of the area around Mt. Touchal.

(S. Iwao and A. Hushmand-Zadeh, 1965)

indistinct columnar joints.

The dacite pyroclastics are pale green and comprise coarse crystal tuffs and fine vitric tuffs, and are intercalated with black shales in the lower and upper part of the member. In the west wall of the Ab-Shar waterfalls, many large, angular, white dacitic blocks, up to $0.5 \mathrm{~m}$ in diameter and showing distinct size-grading, are embedded in a black shaly matrix. It is probably a sort of turbidite, a product of submarine sliding of broken dacite lavas mixed with muddy materials.

Petrographically, all the dacitic rocks mentioned above belong to the "light dacites" of Rittmann (1952), a term denoting dacites which are very poor in mafic minerals and resemble rhyolites. They are absolutely or nearly free of potassium feldspar.

In the several hundred meters of vitric tuffs north of Ab-Shar, small subangular to rounded mudstone fragments are included, suggesting that the sedimentary environment was subject to submarine turbidity currents.

The black shales in the Lower Tuff Member are generally hard and homogeneous and are broken into small elongated pencil-like pieces ("woody shale"). Well-bedded and/or laminated shales with dacite tuff intercalations are frequently seen.

Basic lava flows in the upper part occur north of the village of Suhanak. They are either andesite or basalt, heterogeneous in degree of crystallinity, and partly transitional to rocks of doleritic texture, which also occur as intrusive sills or small dikes. A distinctive sill, accompanied by subsidiary sills, continues for more than $15 \mathrm{~km}$ from Suhanak to Emamzadeh-Davoud. 
The low-grade regional metamorphosed rocks in the Alboz range 271

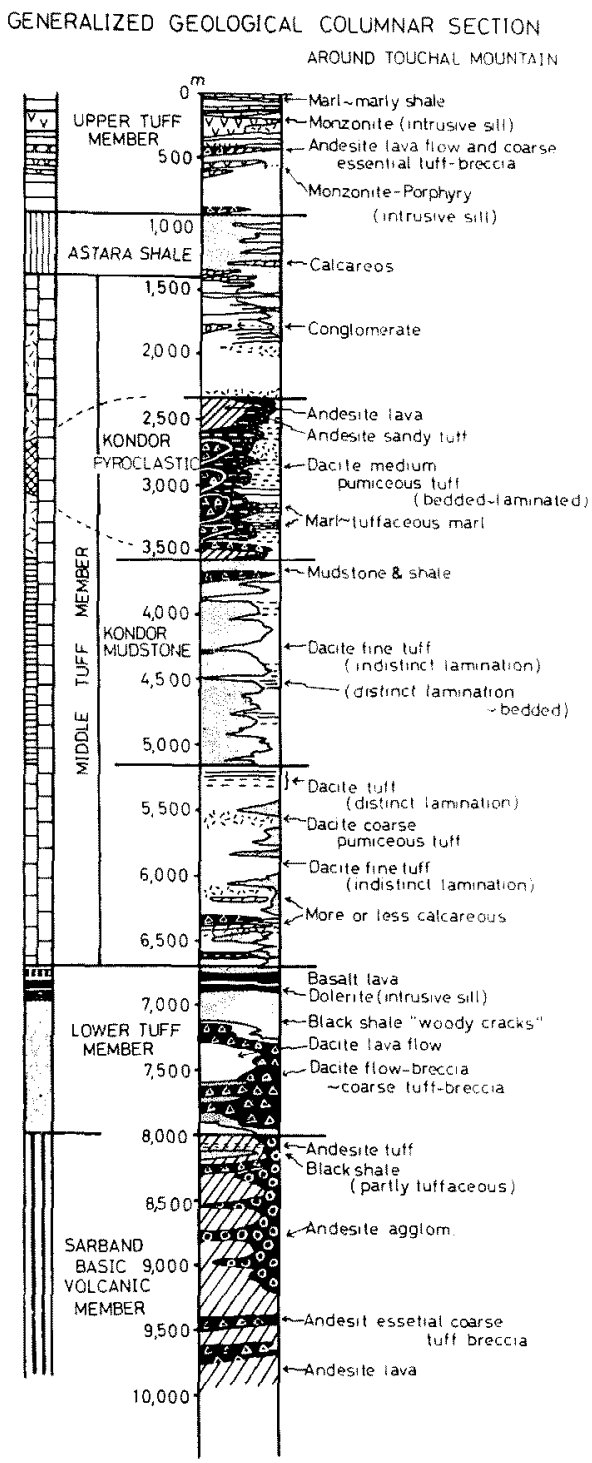

Fig. 4. A generalized geological columnar section around Touchal Mountain, Alborz Range (by S. Iwao \& A. Hushmand, 1965). The patters in the left-hand column are as shown on the legend for the geological map (Fig. 2). 
They are generally subophitic and sometimes even typically ophitic. In some parts they show a texturetransitional to a porphyritic volcanic texture. The thickness of the sills reaches a maximum of about $100 \mathrm{~m}$, but is generally about $50 \mathrm{~m}$.

Albitization and chloritization are in general characteristic of the rocks of this member. Small amounts of sericite, carbonate, quartz, and titanite are also present as secondary minerals. In most of the basic rocks plagioclase is completely altered to albiticheldspar, containg, in places, sericitic, aggregates. In other samples the plagioclase is altered to aggregates of prehnite flakes. Monoclinic pyroxene is nearly colourless and very ofter partly altered to green chlorite of very low birefringence. Formation of secondary quartz and epidotization are not rare.

In the southwestern corner of the area and to the south of Chitgar and Kand, there is a basic member which is denoted as And-Pyr I on the geological map (fig. 2), and composed of andesitic lavas, medium tuffs, and crystal tuffs. It is distinctly stratified, and their general colour is dark greyishgreen due to metamorphism.

This member is conformable with overlying dacitic pyroclastic strata of the Middle Tuff Member. Although its stratigraphic position still remains in question, it can be considered as a separate group.

4. Middle Tuff Member: Thick strata of the Middle Tuff Member overlie conformably the black shale of the Lower Tuff Member. The Middle Tuff Member has the largest exposure of all the members in the area, and its total thickness is about $5,000 \mathrm{~m}$. It is composed mainly of dacitic pyroclastic strata, with subordinate rhyolitic pyroclastics and dacitic lavas and dark-green andesitic pyroclastics. In the lower part, black shales and siltstones (including tuffaceous siltstones) are particularly abundant (e.g., around Randan). In the middle part, marly limestones, marls, and basic lapilli tuffs are present. The top part is rich in dacitic coarse pumice tuffs.

The stratification of the dacitic pyroclastics is generaly distinct, primarily due to variation in grain size (ranging from coarse to fine) and secondarily to variation in the kind of component material (for instance crystal-rich, vitreous, muddy, or calcareous). Double graded bedding (Fiske and Matsuda, 1964) in the pumice-and pumiceous tuffs is also common. Convolution in laminated tuff beds and muddy fragments in the medium and coarse tuffs can be seen in places. The features described above suggest repeated submarine explosive eruptions, rapid accumulation, slumping, and turbidity currents.

The dacite lavas occur as thin intercalations in two different localities. (1) on the $2,400 \mathrm{~m}$ summit northwest of Farahzad; and (2) about $3 \mathrm{~km}$ south of Ahar. They contain brown biotite. 
The low-grade regional metamorphosed rocks in the Alboz range 273

The pyroclastic beds are so numerous that accurate correlation of the different sections is difficult. The coarse-grained beds are thick and have rather massive structure, with big pumiceous or scoriaceous fragments which have been altered to a light-or dark-green material, and sometimes with white plagioclase phenocrysts.

The vitric parts of the fragments appear to be completely altered to aggregates of quartz, albite, and clayey substances, usually chlorite and sericite, sometimes with a mixture of illite and montmorillonite. The pyroclastic beds exposed along the Karaj road have large porphyroblastic crystals of laumontite containing small crystal framents of other minerals such as andesine and/or albite of metamorphic origin. In the rocks free from laumontite, calcite is sometimes predominant. The dacite coarse crystal tuff exposed south of the Karaj dam contains epidote instead of calcite. Dacitic medium-and fine-grained pumice tuffs are similar with respect to original and metamorphic mineral associations. About $1 \mathrm{~km}$ south of Kondor, a hornblende dacite crystal-tuff containg analcite occurs.

The marl in the lower part of the Middle Tuff Member contains abundant crystal fragments of albite, quartz, and chlorite. A characteristic feature of this rock is the inclusion of fragments of highly bituminous mudstone.

In the western half of the area, around Kondor and Wardi, in the middle part of the Middle Tuff Member, the basic pyroclastic strata and the underlying mudstone strata increase considerably in thickness, to about $1,800 \mathrm{~m}$ maximum. They are grouped as the Kondor Pyroclastic Submember, and Kondor Mudstone Submember respectively.

The Kondor Pyroclastic Submember, typically developed south of Kondor, is an alteration of lava flows, tuff breccias, accessory and accidental coarse lapilli tuffs, and crystal tuffs, of pyroxene andesitic composition. Towards the east, however, the lavas thin out and white andesitic crystal tuffs with calcareous cement become predominant. East of Kondor, the andesitic tuffs are rich in nummulitic fragments. Most of the andesite mentioned above is porphyritic, with black, stout, prismatic phenocrysts of monoclinic pyroxene. Tha lava flows which crop out in the village of Kondor are dark green, compact, and aphanitic. The crystal tuff is light brownish-purple and in the field has the appearance of sandstone. Calcic plagioclase, monoclinic pyroxene, lithic andesite fragments and glass fragemnts are cemented in a calcic matrix. The plagioclase and the glass fragments are partly replaced by analcite. In these pyroclastics, in general, chloritization, albitization, carbonatization, and sericitization are widespread, but epidotization is rare.

About $2 \mathrm{~km}$ to the south of Ushan is a small stock of porphyritic pyroxene-andesite which is similarly altered. Several thin beds of dark-green 
andesite coarse crystal-tuff are present in the lower horizons of the Middle Tuff Member.

Overlying the basic pyroclastic strata to the south of Kondor is a local conglomerate bed. It is well stratified, more than $20 \mathrm{~m}$ thick, and contains predominantly rounded, aphanitic andesite pebbles of $1 \mathrm{~cm}$ to $30 \mathrm{~cm}$ in diameter. Small amounts of porphyritic andesite, tuffaceous mudstone, and pale-green dacitic pumice tuff are present as "accessory" pebbles. The cementing material is sandy, calcareous, and/or tuffceous. Several thin layers of muddy and silty tuff are intercalated. This conglomerate indicates a local, short gap during the sedimentation of the Middle Tuff Member. It was probably deposited in a littoral environment around some locally uplifted volcanic islands.

5. Astara Shale Member: Conformably overlying the above-mentioned strata is a alternation of black shales, mudstones, grey siltstones, and pale green or greyish-green dacite tuffs which are termed the Astara Shale Member. It is about $250 \mathrm{~m}$ thick. These rocks are well-bedded or laminated and characterized by the lack of dacitic coarse pumice tuff.

To the north of Kondor, there occurs a thin intercalation of dacite calcareous fine-grained crystal tuff rich in albite crystal fragments. Brown biotite and pilotaxitic dacite fragments are the minor components. As the rock lacks quartz phenocryst fragments, and plagioclase is completely albitized, it loods keratophyric except for calcedonic quartz in the martix. But because of the secondary origin of albite, the present authors prefer the name "dacite".

In the western part, around Kondor, a thin layer of basic tuffs of a few centimeters thick occurs near the base.

Convolute structure in the tuff and tuffaceous mudstone beds is very common. Big fragments of mudstone are very often enclosed, particularly in the tuffs of the lower horizon.

6. Upper Tuff Member: The Upper Tuff Member, which is conformable with the Astara Shale, begins nearly everywhere with massive, dacitic medium tuffs. Around Kondor, however, an andesite coarse tuff breccia, several tens of meters thick, occurs at the base. This is followed by dacite tuffs, overlain in upward succession by $30-70 \mathrm{~m}$ of andesite lava flows, flow-breccias, and tuff breccias. Overlying these is an alternation of coarse pumice tuff and medium-to fine tuff of dacitic composition. Well-bedded and/or finely laminated strata consisting of grey mudstone, siltstone, grey marls, and dacite tuffs of various grain sizes complete the sequence.

The aphanitic dark-grey augite-andesite which occurs as a lava flow around Khur has less than 5 percent phenocrysts of plagioclase and monoclinic 
The low-grade regional metamorphosed rocks in the Alboz range 275

pyroxene. The groundmass is pilotaxitic with acicular crystals of plagioclase and microlites.

An augite-andesite scoria tuff occurs about $6 \mathrm{~km}$ east of Khur. It is composed mainly of brown scoria containing small amount of monoclinic pyroxene and plagioclase. The brown glass of the scoria is heterogeneously metamorphosed. Zeolitization (analcite), albitization, opalization, formation of quartz, chloritization, and montmorillonitization are the main types of metamorphism.

The tuffs of this member are generally siliceous and/or calcareous and are commonly transitional to marls. Typical examples are exposed east of Khur. Pale-brown glass shards of the dacite medium-grained vitric tuff are partly altered to microcrystalline aggregates of quartz, albite, and/or opal. Crystal fragments of andesine or oligoclase and biotite remain fresh. In the dacite fine siliceous tuff, as well as in the tuffaceous marls and calcareous tuffs, secondary albite, calcite, bituminous material, and microfossil fragments are embedded along with microcrystalline aggregates of quartz. Tuffaceous marls with small calcareous nodules are characteristic of the beds about 700 to $800 \mathrm{~m}$ above the base of this member.

Intrusive sills of monzonite and monzonite porphyry protrude in the form of huge walls from the marginal ridge of the synclinal basin around Kondor.

The metamorphic grade of the Upper Tuff Member is generally the lowest in the area. As the metamorphic products from the vitric shards, opal, montmorillonitic minerals, and in places analcite have been recognized. Exceptionally, higher-grade metamorphism has been superimposed on the rocks around the monzonite sills. An actinolite-oligoclase assemblage predominates in the dacitic tuffs a little further from the contact.

7. Conglomerate: The conglomerate formations at the southern foot of Mt. Touchal consist of at least two units of different ages. The older unit forms the rolling hills around Talow-Bala northeast of Tehran, and the younger one the gentle slope at the foot of the mountain. The northern half of the city of Tehran is situated on this slope. The alluvial gravel beds fill up the valleys which are entrenched in the hills. The older conglomerate is composed of angular and subangular blocks derived from the Karaj Formation and is cemented by coarse calcareous-sandy materials. The diameter of the blocks varies from several centimeters to $40 \mathrm{~cm}$. Its stratification is generally distinct, and the beds stand nearly vertical along the fault bordering the Karaj Formation on the south. The younger conglomerate is not very different in composition from the older one, but the boulders are more rounded.

8. Monzonite Sills: Monzonite and porphyritic monzonite occur as 
concordant intrusive sills in the Upper Tuff Member around Khur, and comprise an interior plutonic facies and a marginal porphyritic facies.

A sill exposed in a road cut on the lake side of the Karaj Dam is highly porphyritic at the chilled margin. Near Khur the monzonite and porphyritic monzonite occur side by side as separate sills. The upper age limit of these intrusions is not known in the area.

The principal minerals are thick tabular andesine with rims of potassiumsodium feldspar, monoclinic pyroxene, and green hornblende. In the porphyritic facies, the finer-grained matrix has subophitic texture. Plagioclase, potassium-sodium feldspar, monoclinic pyroxene, opaque minerals, titanite, and apatite are the constituents of the matrix. The plagioclase is generally unaltered and is remarkably zoned. The monoclinic pyroxene shows hourglass structure.

\section{MET AMORPHISM}

1. Mineral Paragenesis and Metamorphic Zoning: As described in the preceding pages there are several kinds of secondary minerals of metamorphic origin in the lava flows as well as in the pyroclastic rocks. They are opal, analcite, montmorillonite, probably illite, laumontite, prehnite, albite, epidote, chlorite, calcite, and titanite. Albite is mostly secondary and replaces the more calcic plagioclase crystals. Calcite, which is mostly a secondary product from silicate minerals in the pyroclastics, also occurs as the recrystallized calcareous cements in the tuffs. The occurrence of laumontite is local.

Since the dacitic rocks persist throughout the Eocene Karaj Formation in the study area, a comparison of mineral paragenesis of the metamorphic rocks at different stratigraphic levels was made (summarised in Table 1) in order to establish the existence or otherwise of metamorphic zoning. As the table shows, three zones were recognized. Thus the Upper Tuff Member forms a zeolite zone, the Astara Shale Member and Middle Tuff Member a transitional zone, and the Sarband Basic Volcanic Member an epidote-chlorite zone (see also Fig. 5).

2. Chemical Composition: Although there is a strong possibility of change in chemical composition from the original rocks, particularly with respect to alkalis, silica, water, carbon dioxide and oxygen, as well as some other "hyperfusible" components, which might have taken place during diagenesis and subsequent metamorphism, other major components and initial petrographic properties of the rocks seem to have been retained.

In Table 3 is presented the chemical composition of three kinds of acid 
The low-grade regional metamorphosed rocks in the Alboz range 277

Table 1. Metamorphic mineral paragenesis in the pyroclastics and lava flows. Arabic numerical lettres indicate metamorphic zones as shown in Fig. 5.

\begin{tabular}{|c|c|c|c|c|c|}
\hline \multirow{2}{*}{ Stratigraphic unit } & \multirow{2}{*}{ Rock } & \multicolumn{2}{|c|}{ III } & \multirow{2}{*}{$\begin{array}{l}11 \\
(3) \\
\end{array}$} & \multirow{2}{*}{$\frac{I}{(4)}$} \\
\hline & & (1) & (2) & & \\
\hline Upper Tuff Member & $\begin{array}{l}\text { andesite } \\
\text { dacite }\end{array}$ & & & $x$ & $\begin{array}{l}x \\
x\end{array}$ \\
\hline Astara Shale Member & $\begin{array}{c}\text { andesite } \\
\text { dacite }\end{array}$ & & & $\begin{array}{l}x \\
x\end{array}$ & \\
\hline Kondor Volcanic Submember & andesite & & & $x$ & $x$ \\
\hline Middle Tuff Member & $\begin{array}{c}\text { andesite } \\
\text { dacite }\end{array}$ & & & $\begin{array}{l}x \\
x\end{array}$ & \\
\hline Lower Tuff Member & $\begin{array}{c}\text { andesite } \\
\text { dacite }\end{array}$ & & & $\begin{array}{l}x \\
\times\end{array}$ & \\
\hline Sarband Basic Volcanic Member & $\begin{array}{c}\text { andesite } \\
\text { dacite }\end{array}$ & $\begin{array}{l}x \\
x\end{array}$ & $\begin{array}{l}x \\
x\end{array}$ & $\begin{array}{l}x \\
x\end{array}$ & \\
\hline
\end{tabular}

(1) epidote-albite-prehnite \pm quartz

(2) epidote-albite \pm quartz

(3) albite-chlorite \pm quartz, original plagioclase is still partly remained.

(4) analcite-opal-chlorite-montmorillonite or opal-montmorillonite, original calcic plagioclase is partly remained fresh, often associated with calcite.

I. Rocks of zeolitic facies

II. Rocks of transitional facies

III. Rocks of subfacies of prehnite-pumpellyite facies

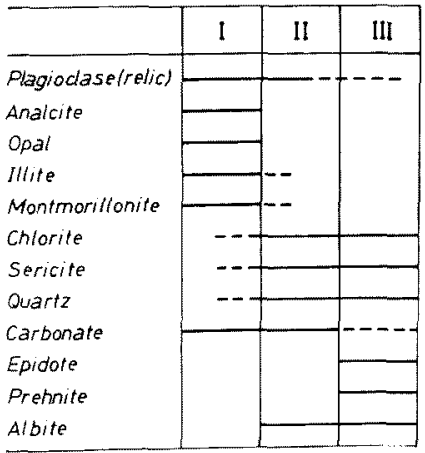

Fig. 5. Metamorphic zones as related to mineral paragenesis in the dacitic pyroclastics. 
Table 2. Chemical composition of the dacite tuffs of Upper Tuff Member (analyst H. Haramura)

\begin{tabular}{l|r|r}
\hline & $(1)$ & $(2)$ \\
\hline $\mathrm{SiO}_{2}$ & 70.38 & 73.09 \\
$\mathrm{TiO}_{2}$ & 0.20 & 0.24 \\
$\mathrm{Al}_{2} \mathrm{O}_{3}$ & 11.83 & 14.07 \\
$\mathrm{Fe}_{2} \mathrm{O}_{3}$ & 0.33 & 0.26 \\
$\mathrm{FeO}$ & 0.37 & 0.22 \\
$\mathrm{MnO}$ & 0.04 & 0.02 \\
$\mathrm{MgO}$ & 0.39 & 0.27 \\
$\mathrm{CaO}$ & 3.31 & 2.64 \\
$\mathrm{Na}_{2} \mathrm{O}$ & 4.82 & 6.67 \\
$\mathrm{~K}_{2} \mathrm{O}$ & 1.38 & 0.54 \\
$\mathrm{H}_{2} \mathrm{O}$ & 0.05 & 0.00 \\
$\mathrm{H}_{2} \mathrm{O}+$ & 7.29 & 1.95 \\
$\mathrm{P}_{2} \mathrm{O}_{3}$ & 0.06 & 0.05 \\
\hline Total & 100.45 & 100.00 \\
\hline
\end{tabular}

(1) No, T. 45 SI : Biotite dacite emerald green fine vitric tuff, with considerable amount of crystal fragments; unaltered original plagioclase crystal fragments (andesine oligoclase) 3\%, quartz 5\%, biotite $<1 \%$, quartzfelsitic matrix with carbonate etc. $70 \sim 80 \%$, green chloritic mineral with montmorillonite $10 \sim 20 \%$, about $9 \mathrm{~km}$ north of Kand.

(2) No, T, 77 SI: Laminated dacite fine vitric tuff, with considerable amount of crystal fragments; secondary albite crystal fragments 1096 , bituminous shale fragments $5 \% \pm$, quartz-felsitic matrix which contains $5 \%$ carbonate and rich in quartz $90 \sim 80 \%$, about $2 \mathrm{~km}$ east of Khur.

tuffs from the Middle Tuff Member. They are apparently rbyolitic (T. 125 SI), quartz keratophyric (T. $20 \mathrm{SI}$ ), and trachytic (T. $157 \mathrm{SI}$ ), respectively. The rhyolitic tuff is composed of essential lithic fragments of which small ones give rise to microcrystalline aggregates of quartz, potassium feldspar, and albite (a product of recrystallization). The potassium-feldspar rim on albitic phenocrysts is still retained. No significant changes in the bulk chemical composition of this rock are suggested. As to the trachytic tuff which was originally rhyolitic, potassium is contained mostly in micaceous clay minerals; the high bulk content of potassium (5.37\%; cf. Table 3) may be explained as due to addition of this component (cf. Equation (1) in the section "Metamorphic Zones"). Albite of the quartz keratophyric tuff is metasomatic (essentially the same as metamorphic) and replaces original plagioclase. Addition of sodium accompaning the formation of calcite is most probable (cf. Equation 
The low-grade regional metamorphosed rocks in the Alboz range 279

Table 3. Chemical composition of the acid tuffs of Middle Tuff Member

(Analyst H. Haramura)

\begin{tabular}{l|r|r|r}
\hline & $(3)$ & $(4)$ & $(5)$ \\
\hline $\mathrm{SiO}_{2}$ & 75.22 & 74.73 & 65.05 \\
$\mathrm{TiO}_{2}$ & 0.33 & 0.31 & 0.79 \\
$\mathrm{Al}_{2} \mathrm{O}_{3}$ & 12.38 & 12.29 & 13.88 \\
$\mathrm{Fe}_{2} \mathrm{O}_{3}$ & 0.42 & 0.51 & 2.42 \\
$\mathrm{FeO}$ & 0.63 & 0.98 & 3.23 \\
$\mathrm{MnO}$ & 0.05 & 0.06 & 0.16 \\
$\mathrm{MgO}$ & 0.45 & 0.56 & 2.02 \\
$\mathrm{CaO}$ & 0.80 & 1.83 & 1.48 \\
$\mathrm{Na}_{2} \mathrm{O}$ & 2.87 & 6.08 & 3.18 \\
$\mathrm{~K}_{2} \mathrm{O}$ & 5.68 & 0.15 & 5.37 \\
$\mathrm{H}_{2} \mathrm{O}-$ & 0.00 & 0.10 & 0.05 \\
$\mathrm{H}_{2} \mathrm{O}+$ & 1.10 & 2.15 & 2.63 \\
$\mathrm{P}_{2} \mathrm{O}_{5}$ & 0.05 & 0.06 & 0.13 \\
\hline Total & 99.98 & 99.81 & 100.39 \\
\hline
\end{tabular}

(3) No T. 125 SI: White rhyolitic medium essential tuff, vitric with considerable amount of crystal fragments; quartz $15 \%$, albite coated by $\mathrm{K}$ feldspar 30\%, quartz-felsitic matrix 50\%, carbonate and others 5\%; about $2 \mathrm{~km}$ north of Ab-Shar, Mt. Touchal.

(4) No. T. 20 SI: Very pale green dacite fine vitric tuff, with considerable amount of crystal fragments; quartz fragments $10 \%$, albitic fragments $15 \%$, carbonate $5 \%$, quartz-felsitic matrix 7096 ; about $4 \mathrm{~km}$ north of Karaj Dam, on the road to Chalus; from top horizon of the Middle Tuff Member.

(5) No. T. $157 \mathrm{SI}$ : Pale green rhyolitic fine vitric tuff, apparently rather trachytic, with emerald green patches of clay mineral aggregates; quartz 5\%, albite 15\%, green K-micaceous clay 20\%, recrystallized vitric shards and other microcrystalline minerals 6096 ; about $1.5 \mathrm{~km}$ southwest of Ahar.

(2)). In this connection it is worth noting that the tuffs of the Upper Tuff Member (cf. Table 2) as well as the upper horizon of the Middle Tuff Member are very rich in sodium. Addition of sodium to the rocks of these stratigraphic horizons is suggested. In most cases sodium is contained in the secondary albite of metasomatic origin, and occasionally it is shared by both albite and analcite.

The laumontite-containing dacite tuffs owe their content of $\mathrm{CaO}$ and $\mathrm{Na}_{2} \mathrm{O}$ to laumontite and albitized plagioclase respectively. The extremely high content of silica in the specimen T. 7 SI (cf. Table 4) cannot be explained 
Table 4. Chemical composition of laumontite containing dacite

(Analyst H. Haramura)

\begin{tabular}{l|r|r}
\hline & $(1)$ & $(2)$ \\
\hline $\mathrm{SiO}_{2}$ & 84.00 & 63.47 \\
$\mathrm{TiO}_{2}$ & 0.12 & 0.38 \\
$\mathrm{Al}_{2} \mathrm{O}_{3}$ & 7.60 & 16.69 \\
$\mathrm{Fe}_{2} \mathrm{O}_{3}$ & 0.12 & 1.75 \\
$\mathrm{FeO}$ & 0.49 & 1.88 \\
$\mathrm{Mno}$ & 0.01 & 0.08 \\
$\mathrm{MgO}$ & 0.22 & 1.81 \\
$\mathrm{CaO}$ & 1.83 & 2.23 \\
$\mathrm{Na}_{2} \mathrm{O}$ & 2.01 & 1.91 \\
$\mathrm{~K}_{2} \mathrm{O}$ & 1.26 & 3.08 \\
$\mathrm{H}_{2} \mathrm{O}$ & 0.00 & 0.50 \\
$\mathrm{H}_{2} \mathrm{O}$ & 2.10 & 5.90 \\
$\mathrm{P}_{2} \mathrm{O}_{5}$ & 0.05 & 0.08 \\
\hline $\mathrm{Total}_{0}$ & 99.81 & 99.76 \\
\hline
\end{tabular}

(1) No. T. 7 SI: Dacite medium pumice tuff, with poikiloblasts of laumontie; Albitized plagioclase $5 \%$. green hornblende $<1 \%$, quartz-felsiticmatrix with epidote, chlorite, rock fragments, etc. $85 \%$, poikiloblasts of laumontite 1096 ; abot $7 \mathrm{~km}$ south of Karaj Dam, on the road to Chalus.

(2) No.T. 18 SI: Dacite medium pumice tuff, with poikiloblasts of laumontite; albitized plagioclase fragments $15 \sim 10 \%$, monoclinic pyroxene <196, quartz-felsitic matrix containing carbonate, epidote, chlorite, an rock fragments, etc.; about $2 \mathrm{~km}$ north of Karaj Dam, on the road to Chalus.

as original composition of dacitic tuff. Under the microscope, silicification is accompanied by zeolitization. As mentioned later, the formation of laumontite in these rocks may be regarded as local metamorphism around monzonite sills.

3. Probable Reactions involved in the Metamorphism: As evident from the metamorphic zoning, the metamorphic grade is shown to have increased generally to the lower stratigraphic horizons (cf. Fig. 7 and Table 1). The transition from Zone I to Zone II is marked by the appearance of a sericitechlorite-albite-carbonate-quartz assemblage as a substitute for the mineral assemblage illite-montmorillonite-analcime and opaline silica. The remains of vitric material, part of the original calcic plagioclase, and mafic minerals also contributed to this new mineral assemblage.

The probable reactions involved in this transition are a sort of dehydration combined with carbonatization as follows: 
The low-grade regional metamorphosed rocks in the Alboz range 281

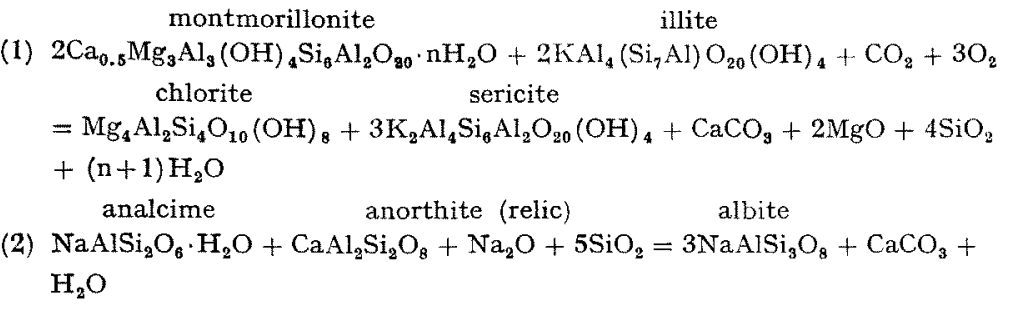

The transition from Zone II to Zone III is characterized by the appearance of epidote and/or prehnite and also by the disappearance of calcite. The reactions are probably as follows:

anorthite (relic) epidote

(3) $3 \mathrm{CaAl}_{2} \mathrm{Si}_{2} \mathrm{O}_{8}+\mathrm{CaCO}_{3}+\mathrm{H}_{2} \mathrm{O}=2 \mathrm{Ca}_{2} \mathrm{Al}_{3} \mathrm{O}(\mathrm{OH}) \mathrm{Si}_{2} \mathrm{O}_{7}\left[\mathrm{SiO}_{4}\right]+\mathrm{CO}_{2}$ anorthite (relic) prehnite

(4) $\mathrm{CaAl}_{2} \mathrm{Si}_{2} \mathrm{O}_{8}+\mathrm{CaCO}_{3}+\mathrm{SiO}_{2}+\mathrm{H}_{2} \mathrm{O}=\mathrm{Ca}_{2} \mathrm{Al}_{2} \mathrm{Si}_{3} \mathrm{O}_{10}(\mathrm{OH})_{2}+\mathrm{CO}_{2}$

To simplify the calculation, the number of calcium cations in montmorillonite molecule is taken as 0.5 .

Actinolite and intermediate plagioclase have still not formed. In fact, the carbonate ratio of the rocks of Zone III is much smaller than Zone II. Epidote and prehnite have formed at the expense of calcite, original plagioclase, and chlorite. This is most clearly dispalyed in the metamorphic halo around a diorite mass which intruded the Eocene lavas and pyroclastics of the Gardaneh-Shir area, Central Iran.

The dissociation temperature of calcite as a single phase is rather high, but coexistence of other phases including silicates and water seems to make it lower. In the calcareous tuffs with excess $\mathrm{CaCO}_{3}$, however, calcite persists.

4. The Metamorphic Environment: Almost all petrographic features in this area suggest a pattern of regional metamorphism, but are never indicative of dislocation of the rocks or shearing. This means that metamorphism proceeded under conditions unfavourable to rapid migration or escape of volatiles and other mobile components in the rocks. The pressure of the volatiles, consequently, might not have been much lower than the rock pressure.

The formation of laumontite, judged from its distribution (see Fig. 6 and Fig. 7) is probably attributable to metamorphism due to the intrusion of the monzonite porphyry sills and superimposed on the low-grade regional metamorphism.

5. Metamorphic features as compared to "Green Tuff" Formation in Japan: The so called "Green Tuff" Formation (a pile of submarine lavas and pyroclastic sediments of Miocene age) in Northeast and Central Japan is 


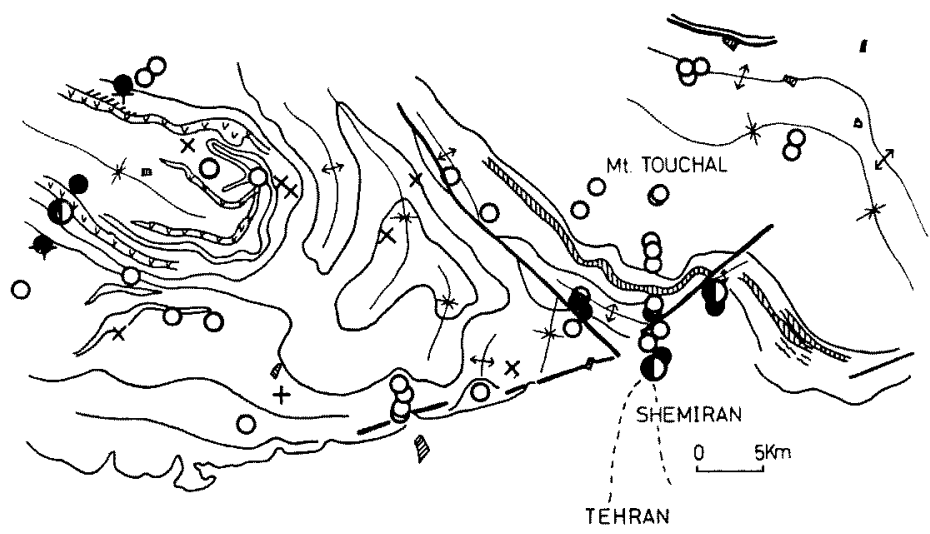

Fig. 6. Localities of the investigated rock specimens around Mt. Touchal. Symbols are as used in Fig. 7.

commonly less than a few kilometers thick, locally reaching about $10 \mathrm{~km}$ (Matsuda, 1962). It is common to find sequences, with a complete series of low-grade metamorphic rocks ranging from almost non-metamorphic to prehnite-pumpellyite facies (Utada, 1946, Iijima 1966, Hashimoto, et al. 1970), roughly correlatable with increase in depth of burial. Frequently, in detail, local or extensive modifications can be recognized.

In the Mts. Touchal area, in spite of the great thickness of volcano-sediments and lavas, reaching $10 \mathrm{~km}$ or more, the range of metamorphic grade is smaller than for the "Green Tuff" formation as commonly reported. This means that the geothermal gradient during the period of metamorphism in this area was in general lower than in the "Green Tuff" area.

It may be noted that pumpellyite, reported from severla localities in the "Green Tuff" area in Japan, as well as from other low-grade metamorphic areas in the world (Coombs 1954, 1959, Wilkinson and Whetton, 1964, Otalora 1964) has not yet been found in the Mts. Touchal area. The present writers, however, have found no evidence that would explain its absence.

Another characteristic feature of the Mts. Touchal area is an extensive development of the rocks of Zone II whose equivalent in the area of the "Green Tuff" formation of Japan has not so far reported as similarly widespread. The present authors, however, suspect that the development of Zone II may be equally extensive in the "Green Tuff" area.

Textural characters of the rocks from Mts. Touchal area and the "Green Tuff' area are almost identical. As previously indicated, the crustal movement 
The low-grade regional metamorphosed rocks in the Alboz range 283

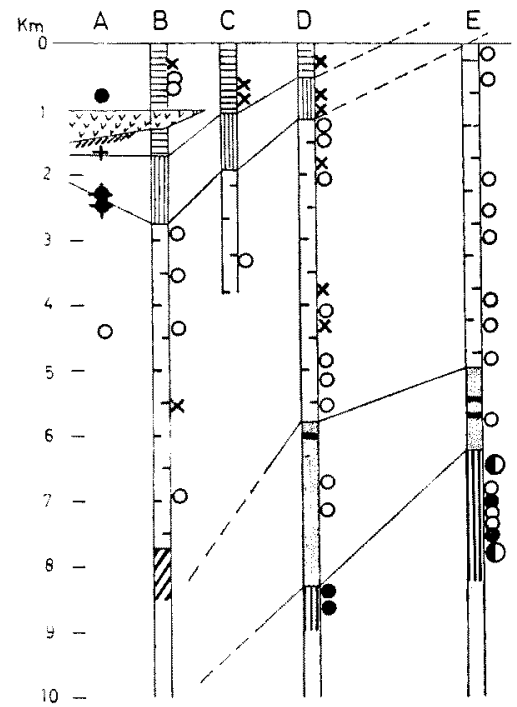

Fig. 7. Metamorphic mineral paragenes is in the rocks in the area around Mt. Touchal, as refered to the burial depth measured from the upper horizon of the Upper Tuff Member. The patterns in the four columns are the same as shown on the legend for the geological map.

Cross

: Analcite-opal-chlorite-montmorillonite-illite or opalmontmorillonite-illite, original plagioclase is partly remained fresh

Open circle : Albite-chlorite-sericite-quartz \pm calcite

Solid circle : Epidote-albite-chlorite \pm sericite-quartz

Semi-solid circle : Prehnite-epidote-albite-chlorite \pm sericite-quartz

Star : Laumontite is contained as major component

Closely hatched : Actinolite-intermediate plagioclase \pm quartz

A: Karaj road, B: Khur-Kondor, C: Sangan-Sulgan, D: Randan-Imamzadehdavoud-Yunjehzar, E: Mt. Touchal-Abshar-Tajrish

represented by folding and conspicuous upheaval of the strata of Karaj Formation was not accompanied by regional development of fissility or schistosity in the rocks. Rocks of the amphibolite-actinolite and grrenschist facies are thus absent (or if present are extremely limited in distribution), even where intrusive masses of monzonite are present. Most other low-grade metamorphic areas cotaining rocks of zeolitic facies have similar charateristics.

Metamorphism of a different character is exhibited by the Tanzawa Mts. area, Central Japan (described in detail by Seki (1969), Sugi (1931) and others). The metamorphosed Miocene basic pyroclastics in this area dispaly remark- 
able schistosity in the zones of higher-grade metamorphism, probably because deformation of the rocks took place during metamorphism accompanied by thrust movements and intrusion of a diorite mass of considerable size. In such an environment, because of a high degree of fissility or density of shear planes in the rocks, it might be natural for the temperature of formation of rocks of any particular metamorphic zone to be lower than in districts where the rocks subjected to metamorphism lack the fissile textures. These textures can favour reduction of the pressure of carbon dioxide and water to a level below that of the rock pressure. This may explain the conspicuous development of the metamorphic rocks of amphibolite-, actionlite-and greenschist facies around the diorite mass in the Tanzawa Mts., in striking contrast to their absence from the Mt. Touchal area.

\section{CONGLUDING REMARKS}

The sequence of events in the area of Karaj Formation around Mts. Touchal., Alborz Range, starting with thick submarine accumulation of mostly volcanic and pyroclastic materials of the dacite (light dacite) and andesite clans and follwed by regional low-grade metamorphism and folding has been virtually ended by uplift of the area against the Quaternary conglomerate area to the south.

The nature of the deposition and metamorphism is more or less similar to that of the Miocene submarine volcanic area in Japanese Main Islands, except that considerable parts of the latter area contain swarms of rich ore deposits of copper, lead, zinc, gold, silver, and gypsum of syngenetic and epigenetic origins closely related to the volcanic activity. The difference in presumed geothermal gradients between these two areas may have to be emphasized.

\section{Reference}

Coombs, D.S. (1954), Tha nature and alteration of some Triassic sediments from Southland, New Zealand, Royal Soc. New Zealand Trans., 82, pt 1. $65 \sim 109$.

Coombs, D.S., Ellis, A.J., Fyfe, W.S., and Taylor, A.M. (1969), The zeolite facies, with comments on the interpretation of hydrothermal syntheses, Geochim. Cosmochim. Acta, 17, 53 107.

Dedual, E. (1967), Zur Geologie des mittleren und unteren Karaj-Tales, Zentral-Elburz (Iran), Thesis Univ, Zürich.

Fiske, R.S. and Matsuda, T. (1964), Submarine equivalents of ash flows in the Tokiwa formation, Japan, Am. Jour. Sci., 262, 76 106.

Hashimoto, M., Seki, Y., Banno, S., and Kojima, G. (1970), Notes on metamorphic facies map of Japan, with Metamorphic Facies Map of Japan 1: 2,000,000. Publication of Geol. Surv. Japan, 1970. 1 17.

Iijima, A. and Utada, M. (1966), Zeolites in sedimentary rocks, with 
refernce to the depositional environmetns and zonal distribution, Sedimentology, 7, 327 357.

Lorenz, C. (1964), Die Geologie des oberen Karadj-Tales (ZentralElburz), Iran. Thesis Univ. Zürich.

Matsuda, T. (1961), The Miocene stratigraphy of the Fuji Rivar Valley, Central Japan, Jour. Geol. Soc. Japan, 67, 79-96 (in Japanese with English abstract).

Matsuda, T. (1962), Crustal deformation and igneous activity in the south Fossa Magna, Japan, "Crust of the Pacific Basin" Geophysical Monograph No. 6, 140-150.

Otalora, G. (1964), Zeolites and related minerals in Cretaceous of east-central Puerto Rico, Am. Jour. Sci., 262. 726 734.

Rittmann, A. (1952), Nomenclature of volcanic rocks. Bull. Volc. Sen. 2. Tom. 12, 75 102 .

Seki, Y., Oki, Y., Matsuda. T., Mikami. K., and Okumura. K. (1969). Metamorphism in the Tanzawa Mountains, Central Japan. Jour. Japan. Assoc. Min. Pet. Econ. Geol. 61, 1 $\sim 75$.

Sugi, K. (1931), On the metamorphic facies of the Misaka series in the vicinity of Nakagawa, Province of Sagami, Japan, Jap. Jour. Geol. Geogr., 9, 87 142.

Utada, M. (1964), Zonal distribution of authigenic zeolites in the Tertiary pyroclastic rocks in Mogami district, Yamagata Prefecture, Sci. Pap. Coll. Gen. Educ Univ. Tokyo, 15, 173 216.

Wilkinson, J.F.G. and Whetten, J.T. (1964), Some analcime-bearing pyroclastic and sedimentary rocks from New South Wales. Jour. Sed. Petr. 34, 543 553 .

\section{北部イラン, エルプルッ山㼣における始新統の低度広域变成岩について}

\section{岩 生 周 一, A. Hushmand-Zadeh \\ 摘 要}

1965 年乙䄪 1 ケ月間調査を行つた結果, 始新統に属する Karaji 層の層序が明らかと

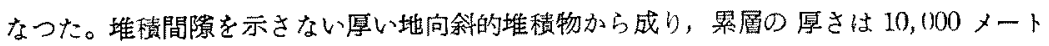
ル以上に達する。熔岩・火山砕首物など火山性堆積物を主とし，泥岩, 泥灭岩なとを爽在 する。火山物質は上・中部の層準では主として酸性，下部層海では主として塩基性である。

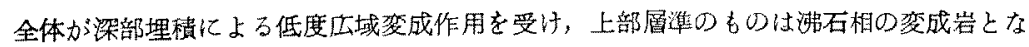
り，下部層準のものはバンベリ石を欠き緑籃石とブドウ石とで特徵付けられる変成岩とな つている。両者の間には潮移带がある。Karaj ダム近くにモンソ二岩々床があ，をれ を围む変成八ローにだけダク沸石が発迲している。

これらの変成作用の梯相は，日本のグリンタフの罢層の大部分と類似するが，全体とし てはもっと楥かな地下温度勾眼の下で行われたものと推定される。 